\title{
THE INFLUENCE OF THE STUDENTS PERCEPTIONS UPON COMPLETION FACILITIES LEARNING AND TEACHERS PEDAGOGIC COMPETENCE TOWARD ECONOMICS LEARNING ACHIEVEMENT
}

\author{
Fitriyah Puspita \\ Pendidikan Informatika, FITK, Universitas Indraprasta PGRI Jakarta \\ fitriyahpuspita23@gmail.com
}

\begin{abstract}
This research aimed at analyzing the relationship of the influence of the student's perceptions upon completion facilities learning and teacher's pedagogic competence toward economics learning achievement. The population was swasta Senior High School's students in Jakarta Utara. The sample taken by random sampling technique, involved 60 students. The instruments were in the forms of questioners and tests, the data were analyzed using multiple regression. The findings showed that : 1) Students's perceptions upon completion facilities learning and teacher's pedagogic competence had significant simultaneous impact on economics learning achievement. 2) Students's perceptions upon completion facilities learning had significant simultaneous impact on economics learning achievement. 3) Teacher's pedagogic competence had significant simultaneous impact on economics learning achievement.
\end{abstract}

Keywords: Facilities Learning, Teacher's Pedagogic competence, Economics Learning achievement

\section{PENDAHULUAN}

Pendidikan adalah upaya meningkatkan kualitas hidup manusia yang bertujuan memanusiakan manusia, mendewasakan dan mengubah perilaku menjadi lebih baik. Pembangunan pendidikan merupakan salah satu prioritas utama dalam agenda pembangunan nasional guna mencapai kemajuan di berbagai bidang kehidupan kita.

Pendidikan bermutu hakikatnya meningkatkan mutu bangsa secara komprehensif. Seperti yang tercantum dalam Undang-Undang Republik Indonesia No. 20 Tahun 2003 tentang Sistem Pendidikan Nasional Bab I Pasal 1 bahwa pendidikan nasional yaitu "Penyelenggaraan pendidikan di Indonesia merupakan suatu sistem pendidikan nasional yang diatur secara sistematis, Pendidikan nasional berfungsi mengembangkan kemampuan dan membentuk watak serta peradaban bangsa yang bermartabat dalam rangka mencerdaskan kehidupan bangsa, bertujuan untuk berkembangnya potensi peserta didik, agar menjadi manusia yang beriman dan bertakwa kepada Tuhan Yang Maha Esa, berakhlak mulia, sehat, berilmu, cakap, kreatif, mandiri dan menjadi warga negara yang demokratis serta bertanggung jawab". 
Research and Development Journal Of Education

Vol. 5 No. 2 April 2019

p-ISSN 2406-9744

e-ISSN 2657-1056

Dengan berorientasi pada fungsi dan tujuan pendidikan nasional tersebut, maka sekolah sebagai salah satu lembaga pendidikan (formal), mempunyai misi dan tugas yang cukup berat guna menghasilkan tunas bangsa yang berkualitas tinggi dalam beragam hal, dan guru atau pihak pendidik harus mampu memberikan yang terbaik dalam proses kegiatan belajar mengajar.

Menurut Undang-Undang Republik Indonesia No 20 Tahun 2003 BAB I pasal 1 menyatakan bahwa "Pendidikan adalah usaha sadar dan terencana untuk mewujudkan suasana belajar dan proses pembelajaran agar peserta didik secara aktif mengembangkan potensi dirinya untuk memiliki kekuatan spiritual agama, pengendalian diri, kepribadian, kecerdasan, akhlak mulia, serta keterampilan yang diperlukan bagi dirinya, masyarakat, bangsa dan negara. Kenyataannya di dalam kehidupan bermasyarakat, bahwa lembaga pendidikan khususnya sekolah-sekolah sebagai lembaga pendidikan formal kurang mampu menampung kebutuhan masyarakat untuk bersekolah, hal ini karena pertambahan jumlah penduduk yang sangat besar, sedangkan kemampuan dan komitmen pemerintah terhadap pendidikan masih rendah.

Di dalam kegiatan belajar mengajar, peranan fasilitas belajar yang mendukung sangat diperlukan. Karena dengan fasilitas belajar yang tersedia, siswa dapat mengembangkan aktivitas dan inisiatifnya secara maksimal dalam melakukan kegiatan belajar. Fasilitas belajar sangat berperan dalam kegiatan belajar mengajar (KBM) karena siswa yang dalam proses belajar mempunyai fasilitas belajar yang lengkap akan lebih mudah mengaplikasikan teori pelajaran yang diberikan secara langsung dengan bantuan fasilitas yang tersedia, maka siswa yang bersangkutan semakin mudah dalam mendapatkan hasil pelajaran dengan baik, bahkan memuaskan.

Kelengkapan dan kelayakan fasilitas belajar di sekolah-sekolah secara umum dapat dilihat dari ketersediaan : (1). Posisi gedung sekolah yang besar dan strategis (2) Seluruh lingkungan sekolah tercipta bersih dan asri (3). Guru terampil menggunakan LCD dan dapat mengoperasikannya (4) Laboratorium yang lengkap (5) Tersedia ruang khusus untuk konseling (6) Tersedia perpustakaan dengan lengkap dan up to date (7) tersedia sarana dan prasarana olahraga (8) Sarana kesehatan sekolah (9) Kantin sehat di sekitar sekolah. Dengan tersedianya fasilitas 
Research and Development Journal Of Education

Vol. 5 No. 2 April 2019

p-ISSN 2406-9744

e-ISSN 2657-1056

belajar yang lengkap dan memadai akan memberikan kenyamanan bagi siswa dan guru dalam proses kegiatan belajar mengajar yang dilaksanakan.

Anderson seperti dikutip oleh Popi Sopiatin (2010:65) menyebutkan bahwa guru yang efektif mempunyai karakteristik yaitu : mempunyai kemampuan yang luas, dan kualitas personal yang baik. Guru adalah ujung tombak pendidikan yang berperan dalam mempengaruhi, membimbing dan membentuk karakter para anak didiknya, karena sejatinya guru adalah perencana, pelaksana, sekaligus sebagai evaluator pembelajaran di kelas. Sedangkan kompetensi pedagogik para guru tersebut sangat dipengaruhi oleh internal dan eksternal.

Prestasi belajar ekonomi artinya suatu keadaan di mana derajat keinginan, harapan dan kebutuhan siswa terpenuhi dalam mata pelajaran ekonomi (Berdasarkan data atau penelitian sebelumnya, mata pelajaran ekonomi dinilai sebagian siswa adalah pelajaran hafalan tanpa makna). Untuk ini, maka prestasi dalam mata pelajaran ekonomi harus di bangun dalam diri mereka bahwa mereka harus memiliki sikap yang bertanggung jawab pada bangsa dan negara, sehingga mereka dapat berusaha maksimal dalam memperlajari ilmu ekonomi dan berusaha ikut berperan mulai dari dirinya sendiri dalam usaha turut mewujudkan kemajuan ekonomi bangsa.

\section{METODE}

Penelitian menggunakan penelitian survei terhadap 60 siswa sebagai responden yang dijadikan sampel penelitian ini, dengan mengambil pengumpulan data menggunakan instrumen yang telah divalidasi tanpa perlakuan terhadap subjek penelitian. Data yang terkumpul di analisis untuk menyelesaikan permasalahan yang dirumuskan dalam bentuk rumusan masalah. Masalah penelitian digambarkan dalam gambar hubungan antar variabel sebagai berikut :

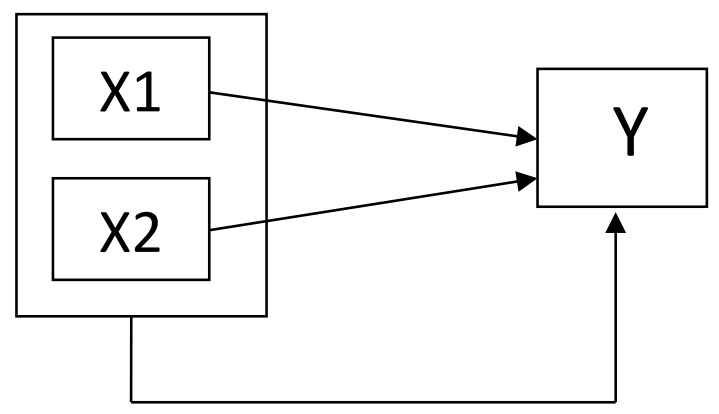

Gambar 1. Desain Penelitian 
Research and Development Journal Of Education

Vol. 5 No. 2 April 2019

p-ISSN 2406-9744

e-ISSN 2657-1056

Keterangan :

$\mathrm{X} 1$ = Persepsi siswa terhadap fasilitas belajar

$\mathrm{X} 2$ = Persepsi siswa terhadap kompetensi pedagogik guru

$\mathrm{Y}=$ Prestasi belajar Ekonomi

Sampel yang digunakan sebanyak 60 siswa, diambil dengan menggunakan tehnik random sampling, menggunakan instrumen angket skala likert untuk mengukur persepsi siswa atas fasilitas belajar dan kompetensi pedagogik guru. Data prestasi belajar dikumpulkan dengan tes yang dibuat berdasarkan silabus mata pelajaran ekonomi untuk siswa Sekolah Menegah Atas. Instrumen divalidasi lebih dahulu secara empiris dengan uji coba instrumen pada responden lain yang tidak dijadikan sampel. Di mana data di analisis terlebih dahulu dengan uji persyaratan yaitu uji normalitas, uji linearitas dan multikolinearitas. Berdasarkan keterpenuhan kriteria dalam uji persyaratan analisis data, dilakukan analisis inferensial untuk pengujian hipotesis penelitian. Analisis inferensial menggunakan tekhnik analisis korelasi dan regresi berganda.

\section{HASIL DAN PEMBAHASAN}

Hasil

Secara deskriptif, data penelitian dapat dinyatakan dalam tabel 1.

Tabel 1. Hubungan antara persepsi siswa atas kelengkapan fasilitas belajar, kompetensi pedagogik guru dan prestasi belajar Ekonomi

\begin{tabular}{lccl}
\hline Statistik & kelengkapan & Kompetensi & Prestasi \\
Deskriptif & fasilitas belajar & Pedagogik guru & Belajar Ekonomi \\
\hline Maksimum & 118 & 121 & 97,50 \\
Minimum & 51 & 54 & 50 \\
Rata-rata & 88,48 & 91,82 & 74,33 \\
Median & 90,50 & 92,50 & 75,00 \\
Std.Deviasi & 16,42393 & 16,66570 & 11,99282 \\
\hline
\end{tabular}

Sumber : Data Primer yang diolah

Dari tabel 1 dapat dilihat bahwa kelengkapan fasilitas belajar tergolong tinggi karena nilai mean dan median mendekati skor maksimal yang mungkin dicapai variabel fasilitas belajar yaitu 118. Variabel kompetensi pedagogik guru juga tergolong tinggi karena nilai mean, dan median mendekati skor maksimal yang mungkin dicapai variabel pedagogik guru yaitu 121. Prestasi belajar Ekonomi dapat dikatakan sedang, karena terlihat dari nilai mean, dan median nilainya masih agak jauh dari skor maksimum yang mungkin dicapai oleh variabel prestasi belajar Ekonomi senilai 97,50. 
Research and Development Journal Of Education

Vol. 5 No. 2 April 2019

p-ISSN 2406-9744

e-ISSN 2657-1056

Sebelum dilakukan pengujian hipotesis, harus dilakukan pengujian asumsi yaitu uji persyaratan analisis data yang meliputi : uji normalitas, uji linearitas dan uji multikolinearitas. Pengujian normalitas dapat dilihat dari gambar diagram scatter plot untuk mengetahui distribusi data setiap variabel yang diteliti normal atau tidak. Pengujian dilakukan dengan menggunakan software SPSS 20.

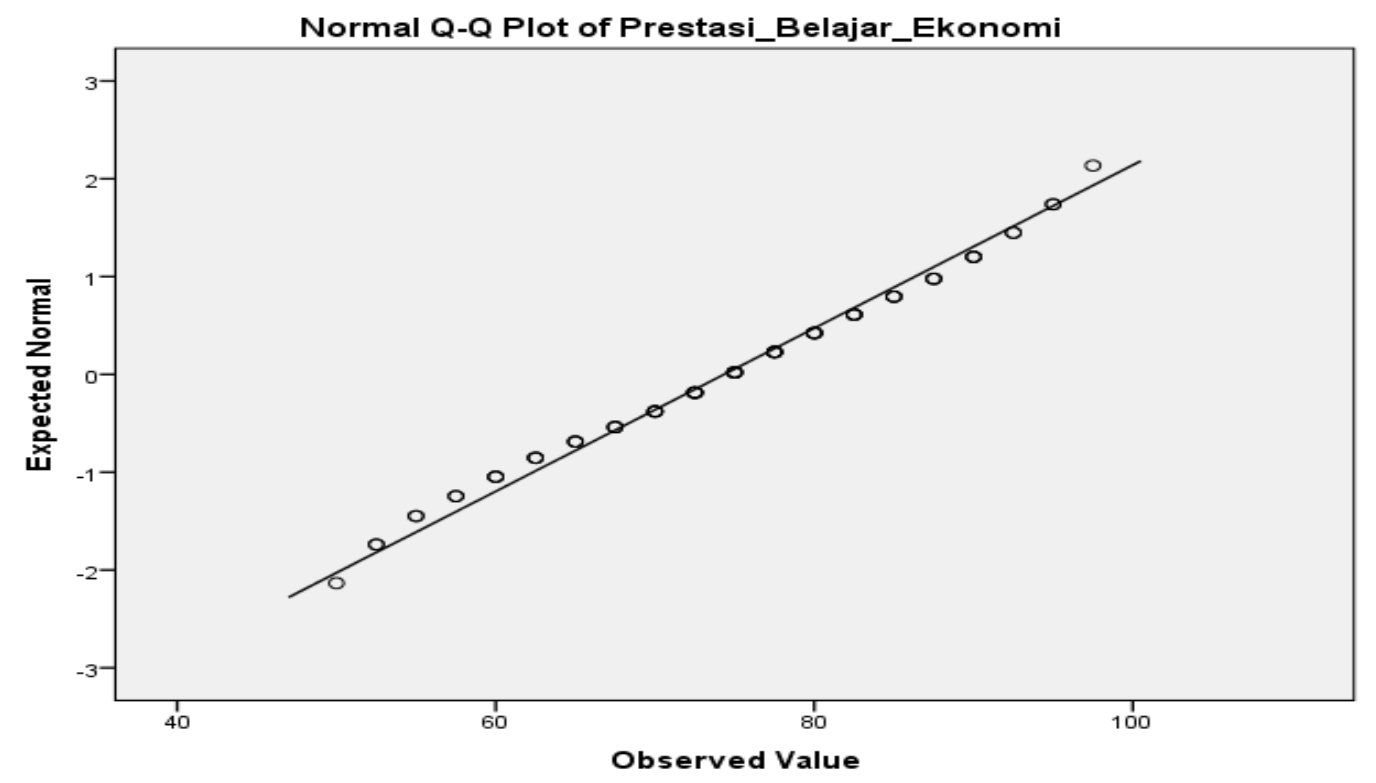

Gambar 2. Scatter Plot Diagram Pencar

Pada gambar tersebut menunjukan bahwa pada data analisis tidak ada pola yang sitematis dari $\mathrm{Z}$ resid, berapapun nilai $\mathrm{Z}$ Pred, sehingga analisis ini menunjukan bahwa tidak terdapat pola heterokedastisitas, sehingga asumsi data yang diolah adalah data homogen dapat terpenuhi dan distribusi sebaran data pada keadaan normal. Pengujian korelasi atau signifikan dapat dilihat pada tabel 2, yang menunjukan bahwa variabel kelengkapan fasilitas belajar memiliki nilai $t_{\text {hitung }}=4,479>t_{\text {tabel }} 1,67$ dan sig. $0,000<0,005$, maka dari hasil pengujian korelasi atau regresi, maka dapat disimpulkan bahwa terdapat pengaruh signifikan variabel bebas kelengkapan fasilitas belajar (X1) terhadap prestasi belajar Ekonomi (Y).

Pengujian korelasi atau signifikan pada tabel 2, juga menunjukan bahwa variabel kompetensi pedagogikk guru memiliki nilai $\mathrm{t}_{\text {hitung }}=4,19>\mathrm{t}_{\text {tabel }} 1,67 \mathrm{dan}$ sig. $0,000<0,005$, maka dari hasil pengujian korelasi atau regresi, maka dapat disimpulkan bahwa terdapat pengaruh signifikan variabel bebas kompetensi pedagogik guru (X2) terhadap prestasi belajar Ekonomi(Y). Sehingga dari hasil 
Research and Development Journal Of Education

Vol. 5 No. 2 April 2019

p-ISSN 2406-9744

e-ISSN 2657-1056

perhitungan SPSS 20,00 pada tabel 2, menunjukan perolehan $t_{\text {hitung }}(X 1)=4,479$ dan $t_{\text {hitung }}(\mathrm{X} 2)=4,19$, menggambarkan bahwa ada pengaruh antara kelengkapan fasilitas belajar (X1) dan kompetensi pedagogik guru (X2) secara bersama-sama terhadap prestasi belajar Ekonomi (Y), dimana besaran koeffisien regresi dan tingkat signifikansi kelengkapan fasilitas belajar lebih besar daripada kompetensi pedagogik guru.

Tabel 2. Ringkasan hasil uji korelasi

\begin{tabular}{llcl}
\hline Variabel & Skor & $p$ & Keterangan \\
\hline $\mathrm{X}_{1} \mathrm{y}$ & $\mathrm{t}_{\text {hit }}=4,479$ & 0,794 & Signifikan \\
$\mathrm{X}_{2} \mathrm{y}$ & $\mathrm{t}_{\text {hit }}=4,19$ & 0,794 & Signifikan \\
\hline
\end{tabular}

Sumber : data primer yang diolah

Uji Multikolinearitas menggunakan koefisien VIF (Variation Inflation Factor) untuk menguji hubungan antar variabel bebas atas ada atau tidaknya hubungan yang kuat antara variabel kelengkapan fasilitas belajar dan kompetensi pedagogik guru Pengujian dilakukan dengan menggunakan software SPSS 20,00 berdasarkan dengan kriteria pengujian jika VIF > 10 atau tolerance menjauhi angka 1, maka terdapat masalah multikolinieritas dan sebaliknya jika VIF $<10$ atau Tolerance mendekati angka 1 berarti tidak terdapat masalah multikolinieritas.

Pada tabel 3 dibawah ini, menunjukan bahwa VIF $<10$ dan Tolerance mendekati angka 1, yaitu VIF 1,602 < 10 dan Tolerance sebesar 0,624 yang artinya mendekati angka 1, maka dapat disimpulkan bahwa tidak terjadi masalah multikolinieritas, dengan kata lain adalah tidak terdapat hubungan yang kuat antara variabel bebas (x1) kelengkapan fasilitas belajar dengan (x2) kompetensi pedagogik guru.

Tabel 3. Hasil Uji Multikolinieritas

\begin{tabular}{llll}
\hline Variabel & Tol & VIF & Keterangan \\
\hline Kelengkapan fasilitas & 0,138 & 7,258 & Tidak terjadi \\
Belajar \&kompetensi & & masalah multi- \\
Pedagogik guru & & & kolinearitas \\
\hline
\end{tabular}

Sumber : Data primer yang diolah.

Setelah semua asumsi pernyataan analisis data terpenuhi, selanjutnya dilakukan perhitungan pengujian hipotesis, yaitu dengan tekhnik korelasi dan regresi ganda, yang proses pengujiannya dilakukan dengan menggunakan program SPSS 20. Dari pengolahaan data diperoleh besar koeffisien korelasi sebesar 0,794; nilai ini mengindikasikan adanya korelasi yang kuat antara kelengkapan fasilitas belajar dan kompetensi pedagogik guru secara bersama- 
Research and Development Journal Of Education

Vol. 5 No. 2 April 2019

p-ISSN 2406-9744

e-ISSN 2657-1056

sama terhadap prestasi belajar Ekonomi. Secara bersama-sama kelengkapan fasilitas belajar dan kompetensi pedagogik guru memberi pengaruh sebesar 79,4 $\%$ terhadap prestasi belajar Ekonomi, dimana sisanya dipengaruhi oleh faktor lain yang tidak dibahas dalam penelitian ini.

Secara individu, signifikansi setiap variabel bebas terhadap variabel terikat ditunjukan melalui nilai $t_{\text {hitung }}$ atau signifikansinya. Hasil perhitungan menunjukan bahwa setiap variabel bebas diperoleh $p<0,05$; sehingga dapat disimpulkan secara individu setiap variabel bebas memberikan pengaruh yang signifikan terhadap prestasi belajar Ekonomi. Persamaan regresi yang terbentuk adalah $16,604+0,333 \mathrm{X}_{1}+0,307 \mathrm{X}_{2}$, Hal ini diartikan bahwa jika kelengkapan fasilitas belajar diabaikan maka prestasi belajar ekonomi 16,604; setiap penambahan 1 point pada kelengkapan fasilitas belajar akan menambah prestasi belajar ekonomi sebesar 0,333 ; dan setiap penambahan 1 point pada kompetensi pedagogik guru maka akan menambah prestasi belajar Ekonomi sebesar 0,307. Hasil uji signifikansi koeffisien regresi diperoleh nilai $F_{\text {hitung }}=48,553$ dengan $p=0,000$; sehingga dapat disimpulkan bahwa koefisien regresi yang terbentuk signifikan, yaitu secara bersama-sama kelengkapan fasilitas belajar dan kompetensi pedagogik guru memberikan pengaruh yang signifikan terhadap prestasi belajar Ekonomi.

\section{Pembahasan}

Penelitian ini telah menemukan dan berhasil mengkonfirmasi bahwa kelengkapan fasilitas belajar dan kompetensi pedagogik guru memberikan dampak yang baik dan berarti bagi kemajuan perkembangan siswa dalam prestasi belajar, khususnya dalam pembelajaran ilmu ekonomi. siswa dapat lebih bersemangat dalam proses belajarnya jika didukung oleh kelengkapan atas fasilitas belajarnya secara menyeluruh.

Jika selama proses kegiatan belajar mengajar (KBM), para siswa dilayani dengan baik, dengan ketersediaan fasilitas belajar yang lengkapo dan memadai serta dapat dimanfaatkan secara maksimal oleh guru dan siswa, maka mereka semua dapat menjalankan proses KBM dengan kondusif dan menyenangkan. Kelengkapan fasilitas belajar lebih signifikan bagi siswa karena fasilitas yang ada mendorong siswa agar lebih pro aktif dan kreatif juga menambah semangat 
Research and Development Journal Of Education

Vol. 5 No. 2 April 2019

p-ISSN 2406-9744

e-ISSN 2657-1056

mereka untuk mengaplikasikan ilmu atau teori yang didapatkannya secara optimal melalui media tertentu dan mendorong siswa untuk suka berlatih tanpa lelah dengan memanfaatkan fasilitas yang ada.

Persepsi merupakan suatu proses tentang petunjuk-petunjuk inderawi/sensori dan pengalaman masa lampau yang relevan diorganisasikan untuk memberikan kepada kita gambaran yang terstruktur dan bermakna pada situasi tertentu (Ruch R.L, 2007 : 300), melalui persepsi awal kita dapat menilai sesuatu yang relevan. Persepsi merupakan tahap paling awal dari serangkaian pemrosesan informasi (Suherman, 2005 : 23), jadi dengan persepsi kita dapat mendeteksi akan sesuatu hal yang kita terima melalui panca indera.

Sarana pendidikan adalah peralatan dan perlengkapan yang secara langsung dipergunakan dan menunjang proses pendidikan, khususnya proses belajar mengajar, seperti gedung, ruang kelas, meja kursi serta alat-alat dan media pengajaran (Mulyasa, 2005 : 49). Prasarana adalah fasilitas yang tidak secara langsung menunjang jalannya proses pendidikan atau pengajaran, seperti halaman, kebun, taman sekolah, jalan menuju sekolah yang semuanya menunjang kelancaran proses belajar mengajar.

Bangunan sekolah yang ideal memiliki kriteria berikut (1). Memenuhi kebutuhan dan syarat pedagogik (2). Aman (3). Memenuhi syarat kesehatan (4).Menyenangkan (5). Dapat memungkinkan untuk diperluas / di tambah luasnya (6) Fleksibel (7) Memenuhi syarat keindahan (8) Ekonomis (J. Mamusung, 2001 : 16), yang secara garis besar, maka suatu gedung sekolah dikatakan layak dan ideal dalam hal kelayakan fasilitas belajarnya adalah yang mempertimbangkan dengan matang mengenai hal dampak lingkungan, nilai ekonomis, daya guna bangunan, desain kelas dan bangunan sekolah.

Kompetensi adalah kemampuan atau kecakapan (Muhibbin Syah, 2010 : 229). Kompetensi adalah pengetahuan, ketrampilan, dan kemampuan yang dikuasai seseorang yang telah menjadi bagian dari dirinya, sehingga ia dapat melakukan perilaku-perilaku kognitif, afektif dan psikomotorik dengan sebaikbaiknya (Mc. Ashan 2001 dalam Mulyasa, 2003:38). Masa depan anak didik dapat cemerlang dan sukses jika diajarkan dan di bimbing oleh guru-guru yang handal memiliki kompetensi yang handal dan relevan, sehingga suasana dan hasil proses kegiatan belajar mengajar dapat terwujud secara efektif dan efisien. Kompetensi 
Research and Development Journal Of Education

Vol. 5 No. 2 April 2019

p-ISSN 2406-9744

e-ISSN 2657-1056

pedagogik adalah kemampuan guru dalam mengelola pembelajaran peserta didik, meliputi merancang pembelajaran, melaksanakan pembelajaran, merancang dan melaksanakan evaluasi, mengembangkan siswa untuk mengaktualisasikan berbagai potensinya serta memahami siswa secara mendalam (Popi Sopiatin, 2010 :67).

Guru yang memiliki kompetensi pedagogik optimal adalah mereka yang memahami wawasan atau landasan kependidikan, memahami peserta didiknya, mampu mengembangkan kurikulum / silabus, merancang pembelajaran dengan baik, melaksanakan pembelajaran yang mendidik dan dialogis, memanfaatkan teknologi pembelajaran, mengevaluasi hasil belajar yang dilaksanakan dan mengembangkan peserta didik untuk mengaktualisasikan berbagai potensi yang dimilikinya, dengan selalu memberi bimbingan, mengenali potansi yang ada dan melatih mereka dengan sangat baik sehingga dapat melayani proses pembelajaran dengan baik dan mendukung para siswanya agar berprestasi sesuai dengan harapan.

Semakin baik kompetensi pedagogik yang dimiliki seorang guru maka semakin baik dalam mengelola proses pembelajaran secara integrasi, terorganisir dan kondusif. Artinya semakin lengkap fasilitas belajar yang ada dan didukung dengan kemampuan kompetensi guru yang optimal akan memberi pengaruh yang baik untuk hasil prestasi belajar para siswa, karena mereka semua dapat memanfaatkan fasilitas yang tersedia secara maksimal dan dapat ter motivasi kuat dari bimbingan para guru yang berkompetensi pedagogik sangat baik.

Pelayanan prima terhadap peserta didik tersebut juga dapat diwujudkan sepenuhnya karena didukung fasilitas dan kompetensi pedagogik yang dimiliki guru. Sehingga siswa layak mendapatkan prestasi belajar terbaik, karena siswa mampu memahami semua materi yang dijelaskan, lalu muncul kedisiplinan dan kerja keras yang sungguh-sungguh sehingga semua harapan terbaik dapat diwujudkan. Siswa yang memiliki fasilitas belajar dan guru-guru yang berkompetensi pedagogik yang tinggi, selain dapat berprestasi dalam menyelesaikan mata pelajaran Ekonomi dengan hasil yang maksimal, dan mampu mengimplementasikan ilmu yang di dapat pada pendidikan formal ke dalam lingkungan sekelilingnya, juga mampu menentukan keberhasilannya dalam kehidupan sosialnya kelak. Karena ketersediaan fasilitas mendorong mereka aktif 
Research and Development Journal Of Education

Vol. 5 No. 2 April 2019

p-ISSN 2406-9744

e-ISSN 2657-1056

dan rajin belajar terus menerus baik di sekolah maupun di rumah, sedangkan kompetensi pedagogik yang dimiliki para guru mendorong para siswa agar lebih peka, rajin, untuk terus belajar dan terbuka menyelesaikan sesuatu serta berusaha gigih demi meraih masa depan sebagai respon untuk menghadapi beragam tuntutan sosial dilingkungan sekitar, kedua hal tersebut perlu diaktualisasikan agar dapat diwujudkan untuk mencapai hasil prestasi yang diinginkan, di mana kelengkapan fasilitas belajar dan kompetensi pedagogik guru mampu mendorong para siswa mencapai hasil maksimal dalam belajarnya.

\section{PENUTUP}

\section{Simpulan}

Pertama, terdapat pengaruh persepsi kelengkapan fasilitas belajar terhadap prestasi belajar ekonomi, yang diartikan semakin tinggi fasilitas belajar siswa, maka semakin baik prestasi belajarnya. Kedua, terdapat pengaruh kompetensi pedagogik guru terhadap prestasi belajar, yang diartikan semakin tinggi kompetensi pedagogik guru, maka semakin baik prestasi belajar para siswanya. Ketiga, terdapat pengaruh kelengkapan fasilitas belajar dan kompetensi pedagogik guru secara bersama-sama terhadap prestasi belajar ekonomi, yang diartikan semakin tinggi kelengkapan fasilitas belajar dan kompetensi pedagogik guru secara bersama-sama, maka semakin baik prestasi belajar para siswanya.

\section{Saran}

Pemerintah, melalui Kementrian Pendidikan dan Kebudayaan membuat kebijakan dan aturan untuk peningkatan kelengkapan fasilitas belajar dan kompetensi pedagogik guru agar mampu mencetak tunas-tunas bangsa yang berkualitas tinggi.

- Pengelola Sekolah, tentunya bekerjasama dengan dinas pendidikan dan instansi terkait untuk melengkapi ketersediaan fasilitas belajar di sekolahnya agar dapat mencukupi kebutuhan sarana prasarana yang dibutuhkan para siswanya.

- Guru, hendaknya terus berusaha meningkatkan kualitas dirinya terutama kompetensi pedagogik yang dimilikinya. 
Research and Development Journal Of Education

Vol. 5 No. 2 April 2019

p-ISSN 2406-9744

e-ISSN 2657-1056

- Kepala sekolah, pengelola pendidikan, instansi terkait, hendaknya turut aktif berperan mengupayakan peningkatan kemampuan kompetensi pedagogik yang dimiliki guru.

- Kepala sekolah, pengelola pendidikan, instansi terkait, hendaknya saling mendukung agar kedua belah pihak dapat saling melengkapi dan mendukung demi prestasi belajar maksimal, baik dalam hal ketersediaan fasilitas maupun kompetensi yang harus dimiliki oleh para guru.

- Siswa, sebagai kaum terpelajar harus dapat berusaha terus mengasah potensi dirinya dengan memanfaatkan fasilitas yang tersedia dan kesigapan kepedulian gurunya untuk meraih impian yang diharapkan.

\section{DAFTAR PUSTAKA}

Arikunto S (2003). Dasar-Dasar Evaluasi Pendidikan. Yogyakarta: Bumi Aksara.

Purwanto M. Ngalim (2007). Tekhnik-Tekhnik Evaluasi Pendidikan. Jakarta: Remaja Rosda Karya.

Ruch. F. L (2007). Developing The Education Environment, Problems and Management. London: Longman scientific and technical.

Suherman (2005). Media Pembelajaran Peranannya Sangat Penting dalam Mencapai Tujuan Pembelajaran. Jogyakarta: Gava Media.

Syah Muhibbin (2000). Quantum Learning Membiasakan Belajar Nyaman dan Menyenangkan. Bandung: Media Utama.

Suparman Ibrahim Abdullah (2013). Aplikasi Komputer Dalam Penyusunan Karya Ilmiah. Jakarta: PT. Pustaka Mandiri.

Syarif Hidayat (2013). Teori Dan Prinsip Pendidikan. Tangerang: Pustaka Mandiri. 